\section{LAWYERS AS THE NEW GUARDIANS OF GOVERNANCE}

A curious thing has happened of late: lawyers have been appointed by the international community as the new guardians of governance for their clients. More specifically, lawyers are increasingly regarded as part of the global efforts to combat money laundering and terrorist financing. How did this come about?

The Financial Action Task Force (FATF), the international body that sets standards for anti-money laundering and combating the financing of terrorism (AML/CFT), has, in its June 2003 revision of the FATF Forty Recommendations on Money Laundering (FATF Recommendations), included lawyers in its coverage when they are engaged in certain activities for their clients. The European Union has done the same in its December 2001 anti-money laundering Directive, which has recently been implemented into domestic law in a number of EU countries. The activities covered by the FATF Recommendations and EU Directive include instances in which lawyers act for their clients in the sale and purchase of real estate and/or businesses or when lawyers handle client money.

These measures require lawyers, notaries, and other independent legal professionals to conduct customer due diligence, maintain records and, more controversially, report any suspicious transaction involving proceeds of crime or funds related to terrorist financing to a selfregulatory body such as a bar association or to a financial intelligence unit (FIU). FIUs are government agencies, such as the National Criminal Intelligence Service (NCIS) in the UK and SEPBLAC in Spain, that receive suspicious transaction reports, analyze those reports, and disseminate their findings to law enforcement authorities for investigation and prosecution.

The requirement for lawyers to report suspicious transactions involving their clients raises various issues, not least issues pertaining to legal professional privilege. And as one might expect, proceedings have been brought in relation to some of these issues, even though the FATF Recommendations and EU Directive are limited to commercial transactions, and do not apply to information received in the course of ascertaining the legal position of clients or in defending or representing clients in legal proceedings.

At the same time, others have challenged the constitutionality of such reporting requirements. The argument is that these reporting requirements strike at the heart of the traditional relationship between lawyers and their clients by undermining the legal professional privilege and, for matters not subject to legal professional privilege, a lawyer's duty of confidentiality to his or her clients.

\section{Articles \\ Good faith in the reform of insurance law 3 \\ Global economic governance and the challenge facing traditional international law in the 21 st century \\ Society and Institute News \\ Articles (cont'd) \\ The Planning and Compulsory Purchase Act 2004 II \\ From Doha to Cancún: a multilateral trading system

It was not so long ago that banks, among others, were making similar arguments - that the need for banking secrecy would prevent banks from reporting suspicious transactions. And yet the reason that banks and lawyers should be covered by AML/CFT laws is the same - to prevent criminals from finding ways to inject illegal money into the economy. Since lawyers who act for clients in commercial transactions are gatekeepers to the larger financial system, shouldn't the need for professional secrecy to protect the attorney-client relationship be balanced against other social interests, including the need to protect the financial system from being used for illicit purposes?

Although the jury remains out on some of these proceedings and indeed more legal challenges might be anticipated, I am optimistic that opposition from the legal profession will moderate over time, as lawyers come to realize that measures to combat money laundering and the financing of terrorism protect not only their clients but also the profession itself.

This is one of a number of issues to be discussed at a conference on Corporate Governance of Financial Institutions presented by the Society for Advanced Legal Studies, and sponsored by Oxford Brookes University and The Journal of International Banking Regulation, October 7 \& 8, 2004 at The Institute of Advanced Legal Studies, Charles Clore House, Russell Square, London WC1. For further information please contact Sue Rogers (email: Sue.Rogers@sas.ac.uk)

\section{Ross Delston}

A consulting counsel at the International Monetary Fund's Legal Department, Washington, DC.

The author may be reached at rdelston@imf.org. The views expressed in this editorial are those of the author and do not

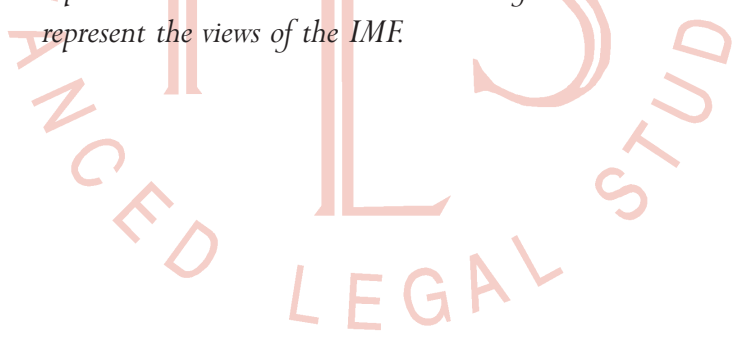

